\title{
地域復興を支える地域産業と人材育成
}

\section{被炙地商工業の再生と 創造的復興}

初澤敏生

\section{はじめに}

東日本大震災は、地域産業が内包する様々な 問題をあぶり出す役割も果たした。筆者は震災 前から福島県南相馬市の地域産業に関して調査 を進めており、震災後も継続的に調査を行って いる。その概要を紹介することにしたい。

南相馬市の中心をなす原町区（旧原町市）は、 福島県の中でも電気機械工業の集積地域として 知られていた。しかし、その生産体制は外来の 大企業を頂点とする下請構造となっており、地 域の新製品開発機能や技術開発機能は低いもの にとどまっていた。そのため、円高が進むと外 来企業は海外に移転し、地域に形成されていた 下請構造も崩壊した。この結果、南相馬市の製 造業は 1991 年をピークとして衰退に転じ、震 災直前の 2010年には1991年に比べて事業所は 6割、従業者数は5 割、製造品出荷額等は4割の 水準にまで落ち込んでいた。このように、地域 産業が崩壊しつつあるところを東日本大震災に 襲われたのである。

\section{発災後の南相馬市の状況}

南相馬市は沿岸部は津波によって大きな被害 を受けたものの、内陸部は地盤が強固であった
こともあり、被害はあまり大きくなかった。し かし、原子力発電所の事故により、状況は急激 に悪化した。震災翌日の3月 12 日には南相馬市 小高区を含む福島第一原子力発電所からの 20 $\mathrm{km}$ 圈内に避難指示が、3月 15 日には同原町区を 含む $20 \sim 30 \mathrm{~km}$ 圈内に屋内退避指示が出され た。原町区の屋内退避指示は 4 月 22 日に緊急時 避難準備区域へと再編され、それは9月30日ま で継続した。

一方、大手の工場は震災後 $1 \sim 2$ 週間で操業 を再開したため、下請企業に部品納入等の指示 を出した。これを受けて、被害の少なかった下 請企業は操業を再開したが、ここで問題となっ たのが、屋内退避指示と緊急時避難準備区域へ の指定である。屋内退避指示は文字通り、屋内 への待避を求めるものであるので、発令中は事 業所の活動が禁止されている。しかし、下請企 業にとっては親企業からの注文を失うことは会 社の存続に関わる問題である。そのため、多く の事業所が屋内退避期間中に操業を再開した。 規則と現実とが大きく食い違っていたのである。 ただし、操業を再開した事業所にとっても、 操業の環境は非常に厳しかった。物流が止まっ てしまったため、業務に必要な資材などの受発 注ができなくなり、生産した製品を福島または仙 台まで持って行って発送する、あるいはそこまで 


\section{PROFILE}

初澤敏生 (はつざわ としお)

福島大学人間発達文化学類教授

專門 経済地理学

届いた原料を受け取りに行くことが求められた。 また、食料等の輸送も途絶えたために生活が困 難になり、多くの従業員が辞めて域外に避難し ていった。このような状況は緊急時避難準備区 域が解除されたあとも、ほぼ半年にわたって継 続した。さらに、取引が不安定になることを恐れ た親企業からの発注打ち切りも相次ぎ、事業所 の操業は縮小せざるを得なかった。南相馬市に おいては、地震や津波の被害よりも原発事故の 影響の方がはるかに大きかったと言える。この結 果、南相馬市のみならず、福島県浜通り地域で は農林水産業のみならず、経済活動全体がストッ プしてしまった。特に避難地域においては、震 災からほぼ10年が経過した本稿執筆時において も、経済活動はまだ震災前水準に戻っていない。

\section{様々な格差の拡大}

ただし、福島県全体を対象とすると工業製品 出荷額は2014年には2010年の水準を回復して いる。これは、震災後の様々な復興政策や補助 金などにより、企業誘致や生産設備の拡充が進 んだためである。論者の中にはこれを持って福 島の復興が進んでいると述べる者もいるが、筆 者はこれには与しない。と言うのも、補助金の多 くは被災地ではない地域での投資に回されたた めである。工場進出を考えるにあたっては、交 通基盤や社会インフラが整った地域に進出する 方が、それらが打撃を受けた被災地に進出する よりも有利である。この結果、県内の地域間格 差は、むしろ震災前よりも拡大した。
筆者が南相馬市原町区で行った調査による と、2010年の売上高を 100 とする指数で示すと、 2011 年には全業種の売上高が 100 を下回るもの の、2012年には建設業が100を超え、2014年に はサービス業も震災前水準を超える売上高を示 している。建設業は2016年には震災前比 176\% に達する。一方、サービス業は最大でも震災前 比 $120 \%$ 程度にとどまり、その伸びは建設業に 比較して小さなものにとどまっている。これは サービス業のうち、成長しているのが自動車レ ンタルやホテル、不動産業など震災復興に関わ るものに限られ、個人向けサービス業は人口の 減少もあって、復旧が遅れているためである。 しかし、建設業は2016年、サービス業は2015 年をピークにして売上高は減少し始める。これ は復興工事や除染工事がピークアウトし、受注 が減少するとともに、地域内で活動する作業員 が大幅に減少したためである。一方、これ以外 の業種の売上高は、震災時からの連続した統計 がとれる2017年までに震災前水準を回復しては いない。2017年現在、製造業は震災前比 $90 \%$ 、 小売業は同 $80 \%$ 、卸売業は同 $70 \%$ 程度の回復に とどまっている。同じ地域においても、業種に よる復興の格差は大きい。

さらに、これを企業別に見ると、最も成長の 著しい建設業においても、震災前の5倍以上の 売上を上げている企業がある一方で、約 4 分の 1 の企業は震災前水準に達していない。これは各 企業の担当する工程などが異なることや、業界 特有の多重下請構造などの影響である。つまり、 復興の進展にあたって地域間格差、業種間格差、 
企業間格差が結びつき合いながら、非常に大き くなっているのである。

\section{労働力をめぐる諸問題}

被災地ではその後も人口の回復が遅れ、地域 産業は様々な課題に直面した。その中で最も重 要な問題が人手不足である。震災後の避難の際 に多くの熟練労働者が退職していった。一般に、 工場では労働者が一人前になるのに十年かかる と言われている（筆者の原町地域でのヒヤリン グによる)。そのような経験を積んだ熟練労働 者が退職してしまったにもかかわらず、特に若 年人口が大幅に減少し、新卒の労働力を確保で きるような状況ではなくなった。このため、中 途採用の労働力に頼って不足する人員の確保を 図ったが、同様の仕事の経験者は少なく、比較 的年齢の高い未経験者を採用せざるを得なかっ た。しかし、年齢の高い未経験者は工場の慣れ ない仕事に耐えることができず、短期間で離職 するケースが続発した。この結果、各企業は頻 繁に採用と初任者教育を繰り返さなければなら なくなった。また、採用した中途採用者は期待 した技術・技能を身につけていないことが多く、 基礎的な教育に長時間を必要とした。従業員が 減り、OJTのための人員を割けない中での新入 社員教育期間の長期化は、各企業に大きな負担 をもたらした。加えて、製造業や建設業では震 災前と比べて賃金水準も $10 \%$ 程度上昇してい る。つまり、各企業は離職率が高く、期待した 技術・技能を持っていないにもかかわらず、賃
金の高い労働者を大量に採用し続ける状況に追 い込まれたのである。

\section{工業復興の方向性}

では、このような打撃を受けた地域をどのよ うに復興させていけばいいのであろうか。筆者 はこのためには「創造的復興」が不可欠であると 考える。前述のように、南相馬市の製造業は震 災前から長期にわたって衰退を続けていた。こ れは地域内の下請関係を中心とする生産構造が、 時代の変化に対応できなくなっていたためであ る。もし、震災前と全く同じ状態に戻せるとし ても、その産業が長期にわたって存続すること はできないであろう。震災から復興し、発展し ていくためには、従来の構造を転換することが 不可欠である。筆者は、このために必要なのは、 下請型構造からの脱皮であると考える。南相馬 市に限らず、福島県（もっと広く東北地方と言っ てもいいかもしれない）の工場の多くは、下請 型の生産構造の中に組み込まれている。これは 東北地方の賃金水準が低く、労働集約型の工業 の立地に適していたためである。しかし、下請 型生産構造の中では地域企業の技術力は向上せ ず、親企業がより安い労働力を求めて海外に移 転すると、地域産業そのものが衰退せざるを得 ない。福島県と山形県が産業空洞化の影響を最 も強く受けたのはこのためである。このような 産業構造の転換が必要である。

このような状況に対応するため、2014年に 「福島イノベーション・コースト構想」が打ち出 
された。これは福島県浜通り地域の産業を復興 するための廃炉技術の開発やロボット産業の振 興などにかかる一大プロジェクトである。ただ し、筆者はこの事業に関しては疑問を持ってい る。それは、これらのプロジェクトが必要とす る技術水準に、多くの地元企業が対応できない 状態であるためである。両者の技術水準の間に 大きな差がある状態では、地元企業は結局新し く進出してきた産業においても下請企業として 活動しなければならず、地域の生産構造を革新 することはできない。

生産構造を革新し、各企業の自立性を高める ためには技術・技能面の向上や新製品企画能力 などの向上が不可欠である。その核となるのが 「人づくり」である。各企業の技術力を上げるた めには、その企業で働く人の技術を上げなけれ ばならない。しかし、福島県の浜通り地域北部 には大学などの高等教育機関は存在しない。工 業分野の人材育成機関は、職業能力開発短期大 学校であるテクノアカデミー浜と小高産業技術 高校に限定される。しかし、これらの卒業生の 多くは大企業に就職し、地元地域の中小企業で は技術力を持った新卒の従業員の雇用は困難で ある。この状況は、震災後さらに厳しくなって いる。このような状況下で地域企業の技術力を 上げるには、既就業者への研修等の再教育が不 可欠である。筆者は、2019年に南相馬市に設置 された福島県ハイテクプラザ (工業試験場) 南相 馬技術支援センターの人材育成機能に期待して いる。今、福島県浜通り地域に必要なのは、大 規模な予算を投入するビッグプロジェクトでは
なく、個々の企業で働く人々の技術力を高めて いくための活動ではないだろうか。非常に地味 な活動であるが、その向こうにこそ創造的な復 興が存在しているのだと考えている。

\section{商業振興の課題}

このように、工業に関しては困難ではあるも のの、復興への方向性が見えている。しかし、 商業の復興に関してはより困難が大きい。商業 の振興はその地域の商圈人口に依存するところ が大きいため、人口の回復が産業復興の条件と なる。南相馬市の原町区は商業中心地でもあっ たことから、南は浪江町、西は飯舘村も商圈に 含んでいた。しかし、小高区、浪江町、飯舘村 が避難地域に指定され、また、小高区以外の南 相馬市も大きく人口を減らす中で、南相馬市の 商業も衰退せざるを得なかった。人口の回復が 遅れる中で、商業の復興は困難に直面している。

被災地域を復興させるためには生活インフラ となる各種商店等が必要である。しかし、それ らの商店を維持するには一定の人口が必要とな る。まさに「鶏が先か卵が先か」の議論である。 これに対応するためには行政が一定の役割を果 たして地域の商業を維持していかなければなら ないが、その動きは必ずしも十分ではない。地 域の「新しいまちづくり」をどのように進めたら いいのか。それを考えるためには一定の時間と 議論が必要であるが、それが長引くほど地域の 復興も遅れる。行政にはスピード感を持った対 応を期待したい。 